Article

\title{
The Effects of Saline Stress on the Growth of Two Shrub Species in the Qaidam Basin of Northwestern China
}

\author{
Tan Zhang, Zhenzhong Zhang, Yuanhang Li and Kangning He * \\ College of Soil and Water Conservation, Beijing Forestry University, Beijing 100083, China; \\ zhangtan@bjfu.edu.cn (T.Z.); castortroy@bjfu.edu.cn (Z.Z.); ys544358252@yahoo.com (Y.L.) \\ * Correspondence: hkn@bjfu.edu.cn; Tel.: +86-010-6233-8356
}

Received: 13 January 2019; Accepted: 31 January 2019; Published: 5 February 2019

check for updates

\begin{abstract}
Soil salinization is a serious issue in the Qaidam Basin and significantly limits economic development. To explore the salt tolerance of two shrubs in this area, we determined several parameters, including the Soil and Plant Analyzer Development (SPAD), net photosynthetic rate $\left(P_{n}\right)$, transpiration rate $\left(T_{r}\right)$, intercellular carbon dioxide $\left(C_{i}, \mu \mathrm{mol} \mathrm{mol}^{-1}\right)$, stomatal conductance

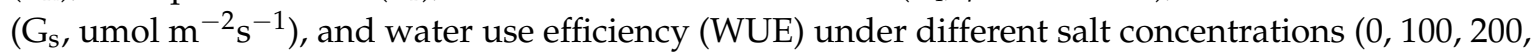
300 , and $400 \mathrm{mmol} \cdot \mathrm{L}^{-1}$ ). In addition, the shrubs of Elaeagnus angustifolia and Lycium barbarum of salt tolerance were evaluated. The photosynthetic parameters of E. angustifolia were more sensitive to salinity than those of L. barbarum, and SPAD, $\mathrm{P}_{\mathrm{n}}, \mathrm{T}_{\mathrm{r}}$, and WUE of E. angustifolia decreased significantly with increasing salt concentrations $(p<0.05)$, while in L. barbarum, SPAD, $\mathrm{P}_{\mathrm{n}}$, and $\mathrm{T}_{\mathrm{r}}$ decreased significantly with increasing salt concentrations $(p<0.05)$, but the WUE of L. barbarum showed no significantly variation under the salt concentration gradient. The results of correlation matrix of photosynthetic index also indicated that the minimum salt tolerance of E. angustifolia and L. barbarum were 108.4 and $246.3 \mathrm{mmol} \cdot \mathrm{L}^{-1}$, respectively. Our results provide a scientific basis for the selection of salt-tolerant plant species in of northwest China.
\end{abstract}

Keywords: salt tolerance; WUE; salt concentrations; photosynthetic parameters

\section{Introduction}

Soil salinization has become an issue of global concern [1] and significantly threatens food and resource security [2-4]. It not only leads to the destruction of resources and the loss of agricultural production, but also negatively impacts the environment and economic development $[5,6]$.

In China, the total area of saline-alkaline soil accounts for about $3.69 \times 10^{5} \mathrm{~km}^{2}$, and the potential saline soil area is about $1.73 \times 10^{5} \mathrm{~km}^{2}$ [7]. Several engineering water conservancy measures, chemical measures, biological measures, and comprehensive measures are available to improve and use saline-alkaline land [8-10]. Of these, biological measures, such as the planting of suitable plants, are the most cost-effective approach to utilize and improve saline-alkali land [11]. Salt-tolerant plants can improve saline-alkaline soil structure, increase soil nutrients, and therefore improve the ecological environment [12]; in addition, such an approach can promote economic development.

The most direct effect of salinity on plants is growth inhibition via impacting water absorption, thereby leading to reduced plant height, lower DBH, fresh and dry weight, and inhibited plant organ differentiation [13-16]. In addition, the increase in $\mathrm{pH}$ caused by high saline levels also negatively impacts plant growth via changes in metabolism, nutrient absorption, and ion balance [17]. Previous studies on the impacts of soil salinity have mostly focused on plant ion metabolism, hormone responses, enzyme activity, water physiology, and growth characteristics [18-21], while only a few 
studies investigated photosynthesis under $\mathrm{NaCl}$ salt stress [22,23]. Most commonly, salt stress is induced by excessive amounts of $\mathrm{NaCl}$ in the soil, which is a frequent problem in northern China. Several plant species, such as Elaeagnus angustifolia, Lycium barbarum, Suaeda salsa, and Tamarix chinensis, can grow on saline-alkaline soils, and it is of particular importance to investigate the adaptability of different plant species to salt stress, facilitating the selection of salt-tolerant plant species.

The Qaidam Basin is an important industrial production base in northwestern China and one of the largest areas with saline-alkaline soil, low annual precipitation and high salinity. The species $E$. angustifolia and L. barbarum are largely cultivated in the area and are of significant economic importance. However, in recent years, yields have been declining due to increasing salt stress. In this context, we determined the photosynthetic parameters of E. angustifolia and L. barbarum to: (i) explore the adaptability and physiological mechanism of salt tolerance under $\mathrm{NaCl}$ salt stress; (ii) to evaluate the maximum salt tolerance threshold of these species under $\mathrm{NaCl}$ salt stress. The overall aim of the study is to provide a scientific basis for species selection in ecological construction programs.

\section{Materials and Methods}

\subsection{Study Sites}

The study area was located at the Nomuhong Farm $\left(96^{\circ} 15^{\prime}-96^{\circ} 35^{\prime} \mathrm{E}, 36^{\circ} 20^{\prime}-36^{\circ} 30^{\prime} \mathrm{N}\right)$ in Qinghai Province, China, $637 \mathrm{~km}$ from Xining and $147 \mathrm{~km}$ from Golmud City. The area is an arid desert with a plateau continental climate. The farm covers an area of $5 \mathrm{~km}$ from north to south and $30 \mathrm{~km}$ from east to west, with a total area of $91.3 \mathrm{~km}^{2}$ at an elevation of $2790 \mathrm{~m}$ (Figure 1). The growing season is relatively short and extends from June to September. Average annual rainfall is $43.5 \mathrm{~mm}$, with an annual potential evapotranspiration of $2849.7 \mathrm{~mm}$. Solar radiation is strong, and the area receives more than $3100 \mathrm{~h}$ of sunshine per year. Average annual temperature is $4.9^{\circ} \mathrm{C}$, with distinct differences between day and night. Annual maximum and minimum temperatures are 35.8 and $-31^{\circ} \mathrm{C}$, respectively. The frost-free period is 70 days, and the salt mainly consists of chloride salt and sulfate. The soil layer in the study area is thicker, and the soil is mainly gray brown desert soil and saline desert soil. The soil PH in the study was 8.1. The soil C, N, P and K were $0.69 \mathrm{~g} / \mathrm{kg}, 0.05 \mathrm{~g} / \mathrm{kg}, 6.15 \mathrm{mg} / \mathrm{kg}$ and $254.4 \mathrm{mg} / \mathrm{kg}$. The vegetation mainly consists of desert species such as Elaeagnus angustifolia, Lycium barbarum, Tamarix hispida, and Nitraria tangutorum.

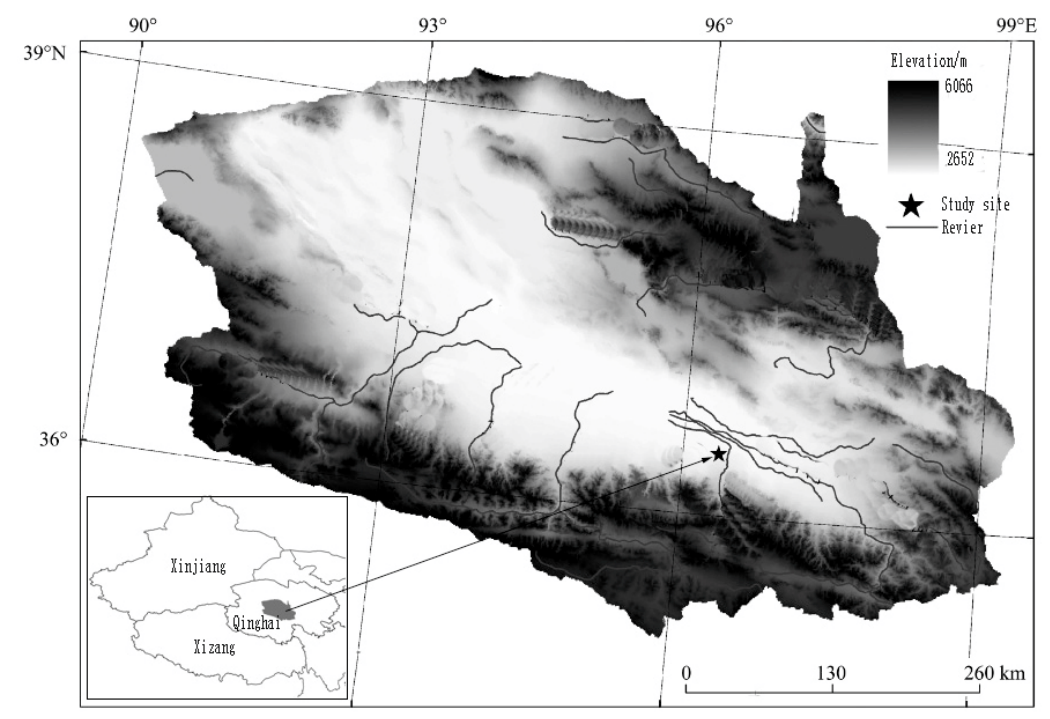

Figure 1. Geographic map of the study area. 


\subsection{Experimental Design}

On April 20, 2016, 180 shrubs (90 of E. angustifolia and 90 of L. barbarum), with relatively uniform growth were selected and each plant was transplanted into a plastic basin with a diameter of $32 \mathrm{~cm}$ and a height of $30 \mathrm{~cm}$. The basins placed in the greenhouse of the Nomuhong Farm. At the bottom of the basins, a hole was drilled manually and covered with gauze to prevent soil loss. Each plastic basin was placed in a 2 -mm sieve with a mass of $1.8 \pm 0.05 \mathrm{~kg}$, rinsed, and air-dried. Hoagland nutrient solution was regularly applied during the cultivation period, and the plants were irrigated to ensure adequate growth. On July 2, 2016, shrubs with consistent growth (average height and diameter at breast height, DBH) were selected for the determination of the initial growth parameters (Table 1).

Prior to the application of salt stress, according to the water holding capacity in the field and the related drought stress test, the soil water content of all seedlings was maintained at about $17 \%$. For the salt stress treatment, one control group (CK) and four $\mathrm{NaCl}$ salt treatment groups were subjected to each treatment, using six replicates. Dissolve $\mathrm{NaCl}$ solvent in water to prepare solution in proportion. The salt concentrations were 0 (CK), 100 (S1), 200 (S2), 300 (S3), and 400 (S4) $\mathrm{mmol} \cdot \mathrm{L}^{-1}$.

The salt solution was prepared for the corresponding mass of analytically pure $\mathrm{NaCl}$ and Hoagland nutrient solution $(\mathrm{pH}=6)$. To prevent salt-exciting reactions, the salt concentration was treated by adding $50 \mathrm{mmol} \cdot \mathrm{L}^{-1}$ per day until the predetermined concentration of each treatment was reached. The same amount of Hoagland nutrient solution was added to the control group. To obtain the response of salt date to salt stress in the natural environment, the shrubs were moved to the open space every morning for natural light irradiation and were placed back into the greenhouse at night. Every evening, the plants were weighted and soil moisture was determined with $\mathrm{ECH} 2 \mathrm{O}$ soil moisture sensor (Decagon, USA). Water was supplemented accordingly.

Table 1. Growth parameters of the different shrub species.

\begin{tabular}{|c|c|c|c|c|c|c|c|c|c|c|c|c|}
\hline \multirow{2}{*}{ Species } & \multirow{2}{*}{ Height (cm) } & \multirow{2}{*}{$\mathrm{DBH}(\mathrm{cm})$} & \multicolumn{2}{|c|}{ CK } & \multicolumn{2}{|c|}{ S1 } & \multicolumn{2}{|c|}{ S2 } & \multicolumn{2}{|c|}{ S3 } & \multicolumn{2}{|c|}{ S4 } \\
\hline & & & $\mathrm{NaCl}$ & EC & $\mathrm{NaCl}$ & EC & $\mathrm{NaCl}$ & EC & $\mathrm{NaCl}$ & EC & $\mathrm{NaCl}$ & EC \\
\hline Elaeagnus angustifolia & $57.94 \pm 0.78$ & $1.27 \pm 0.08$ & 0 & 0 & 100 & 47 & 200 & 95 & 300 & 145 & 400 & 196 \\
\hline Lycium barbarum & $40.28 \pm 0.49$ & $1.26 \pm 0.06$ & & & & & & & & & & \\
\hline
\end{tabular}

DBH is diameter at breast height; $\mathrm{CK}$ is control check; $\mathrm{S} 1, \mathrm{~S} 2, \mathrm{~S} 3, \mathrm{~S} 4$ are $\mathrm{NaCl}$ at concentrations of 100, 200, 300 and $400 \mathrm{mmol} \cdot \mathrm{L}^{-1}$, respectively. The unit of the $\mathrm{NaCl}$ and $\mathrm{EC}$ were $\mathrm{mmol} \cdot \mathrm{L}^{-1}$ and $\mathrm{us} \cdot \mathrm{cm}^{-1}$, respectively.

\subsection{Determination of Meteorological Parameters}

Three Davis Vantage Pro 2 small weather stations were set up next to the greenhouse to continuously determine relative humidity $(\mathrm{RH}, \%)$, solar radiation $\left(\mathrm{Rs}, \mathrm{W} \cdot \mathrm{m}^{-2}\right)$, and temperature $\left(\mathrm{T},{ }^{\circ} \mathrm{C}\right)$ at an interval of $15 \mathrm{~min}$. Saturated vapor pressure difference (VPD, kpa) was calculated by formula as follows:

$$
\mathrm{VPD}=0.611 \times \mathrm{e}^{\frac{12.27 \times \mathrm{T}}{237.3 \times \mathrm{T}}} \times\left(1-\frac{\mathrm{RH}}{100}\right)
$$

where $\mathrm{T}$ is the temperature and $\mathrm{RH}$ is the relative humidity.

\subsection{Determination of Physiological and Biochemical Indicators}

\subsubsection{Leaf SPAD Value}

Soil and Plant Analyzer Development (SPAD) values can reflect the relative content of chlorophyll and were measured by the portable SPAD-502 m emitting red light $(650 \mathrm{~nm})$ and infrared light $(940 \mathrm{~nm})$ via transmission. The relative content of chlorophyll (SPAD value) can be obtained by the difference of the optical density between the two wavelengths [18]. To prevent interference by different parts of plant leaves, three leaves in the middle of each plant were selected for the measurement, and each measurement was repeated three times. 


\subsubsection{Photosynthetic and Transpiration Processes}

After 20 days of shrub growth, on a sunny day, the photosynthetic parameters of leaves at the same leaf position were measured using a Licor-6400 portable photosynthesis system at intervals of $2 \mathrm{~h}$. Determination times were 7:00, 9:00, 11:00, 13:00, 15:00 17:00, and 19:00. The measured parameters included net photosynthetic rate $\left(\mathrm{P}_{\mathrm{n}}, \mathrm{umolm}^{-2} \mathrm{~s}^{-1}\right)$, transpiration rate $\left(\mathrm{T}_{\mathrm{r}}, \mathrm{umol} \mathrm{m} \mathrm{s}^{-2} \mathrm{~s}^{-1}\right)$, intercellular carbon dioxide $\left(C_{i}, \mu \mathrm{mol} \mathrm{mol}^{-1}\right)$, and stomatal conductance $\left(G_{s}, u_{m o l ~ m}^{-2} \mathrm{~s}^{-1}\right)$. Five groups of data were recorded continuously after the numerical stability of each index measurement. Because the default leaf area of the Licor-6400 portable photosynthetic meter is $6 \mathrm{~cm}^{2}$, to ensure the reliability and accuracy of the data, the observed results had to be recalculated. At the end of the experiment, scanners were used to scan the labeled leaves, and the leaf area was calculated by the pixel ratio. The photosynthetic indices were recalculated using the LI6400 Sim 5.3 software (LI-COR, Washington, DC, USA), and the water use efficiency (WUE) of the leaves was calculated as follows:

$$
\mathrm{WUE}=\frac{\mathrm{P}_{\mathrm{n}}}{\mathrm{T}_{\mathrm{r}}}
$$

where WUE is the water use efficiency and $P_{n}\left(\right.$ umolm $\left.^{-2} \mathrm{~s}^{-1}\right)$ and $T_{\mathrm{r}}\left(\mathrm{umolm}^{-2} \mathrm{~s}^{-1}\right)$ are net photosynthetic rate and transpiration rate, respectively.

\subsubsection{Measurement of Light Response}

After 20 days of shrub growth, the leaves at the same leaf position were clamped using the Licor-6400 portable photosynthesizer with a red-blue light source for photosynthesis response measurement. Prior to observation, the temperature of the photosynthesizer was adjusted to $25^{\circ} \mathrm{C}$, while the $\mathrm{CO}_{2}$ level was set to $380 \mu \mathrm{mol} \cdot \mathrm{mol}^{-1}$. The gradient of photosynthetic active radiation was $2500,2000,1800,1600,1400,1200,1000,800,600,400,200,150,100,50$, and $0 \mu \mathrm{mol} \cdot \mathrm{mol}^{-1}$. The leaves used for measurement were first induced by light at $1500 \mu \mathrm{mol} \cdot \mathrm{mol}^{-1}$ light intensity for $30 \mathrm{~min}$, and subsequently, the automatic program of the instrument was used to carry out light induction.

The plant light response curve can be fit in two ways, namely by non-right hyperbola fitting and by right hyperbola fitting. Previous studies have shown that non-rectangular hyperbola fitting has more physiological significance [8]; it was therefore used in the present study. The calculation formula is as follows:

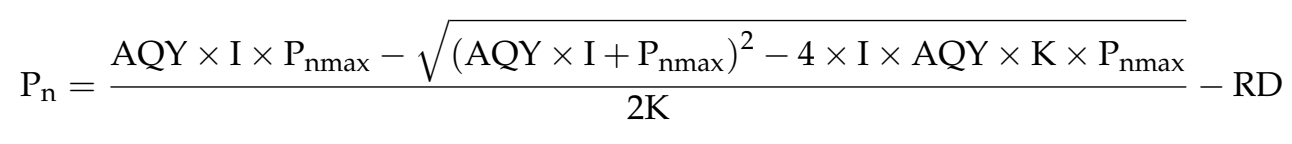

where $P_{n}$ and $P_{n m a x}$ are the net photosynthetic rate and the maximum net photosynthetic rate $\left(\mu \mathrm{mol} \cdot \mathrm{m}^{-2} \cdot \mathrm{s}^{-1}\right)$, respectively; I is the photosynthetic active radiation $\left(\mu \mathrm{mol} \cdot \mathrm{m}^{-2} \cdot \mathrm{s}^{-1}\right) ; \mathrm{K}$ is the curved angle; AQY is the initial quantum efficiency $\left(\mathrm{mol} \cdot \mathrm{mol}^{-1}\right)$; RD is the dark breathing rate $\left(\mu \mathrm{mol} \cdot \mathrm{m}^{-2} \cdot \mathrm{s}^{-1}\right)$. When the regression curve intersects with the $\mathrm{x}$-axis $(\mathrm{I})$, the corresponding light intensity represents the light compensation point (LCP), and when $\mathrm{P}_{n}$ takes the maximum value, the corresponding light intensity represents the light saturation point (LSP).

\subsection{Statistical Analysis}

All statistical analyses were performed using the software package SPSS 16.0 (IBM, New York, NY, USA). Descriptive statistics was used to calculate the mean and standard deviations for each set of replicates. All data was tested for normal distribution and homogeneity of the variance analysis to ensure that the data met the requirements of the variance analysis. Firstly, a two-way ANOVA was used to analyze the differences in SPAD, $P_{n}, T_{r}$, and WUE, with treatment and species as independent factors. The LSD method was used to compare the SPAD, $\mathrm{P}_{\mathrm{n}}, \mathrm{T}_{\mathrm{r}}$, and WUE when necessary. 


\section{Results and Discussion}

\subsection{Basic Meteorological Characteristics}

The daily average values of radiation and VPD were $657.3 \mathrm{~W} \cdot \mathrm{m}^{-2}$ and $1.48 \mathrm{KPa}$, respectively. The variation of solar radiation was a single peak, reaching its maximum of $1123 \mathrm{~W} \cdot \mathrm{m}^{-2}$ at 13:00 (Figure 2). Similar to radiation, the variation of saturated water vapor pressure also consisted of a single peak, reaching its maximum of $2.01 \mathrm{KPa}$ at $13: 00$. Average daily temperature was $19.0^{\circ} \mathrm{C}$, with a maximum of $22.2^{\circ} \mathrm{C}$ at $13: 00$ and a minimum of $14.3^{\circ} \mathrm{C}$ at $7: 00 \mathrm{am}$. Relative humidity was negatively correlated with the above-mentioned indices; it first decreased and then increased. Generally, at 15:00, humidity was $27 \%$. The soil and water content of CK in E. angustifolia and L. barbarum were $17.0 \%$ and $16.8 \%$, respectively. There was no significant difference in soil water content among the four treatments of E. angustifolia and L. barbarum, respectively.
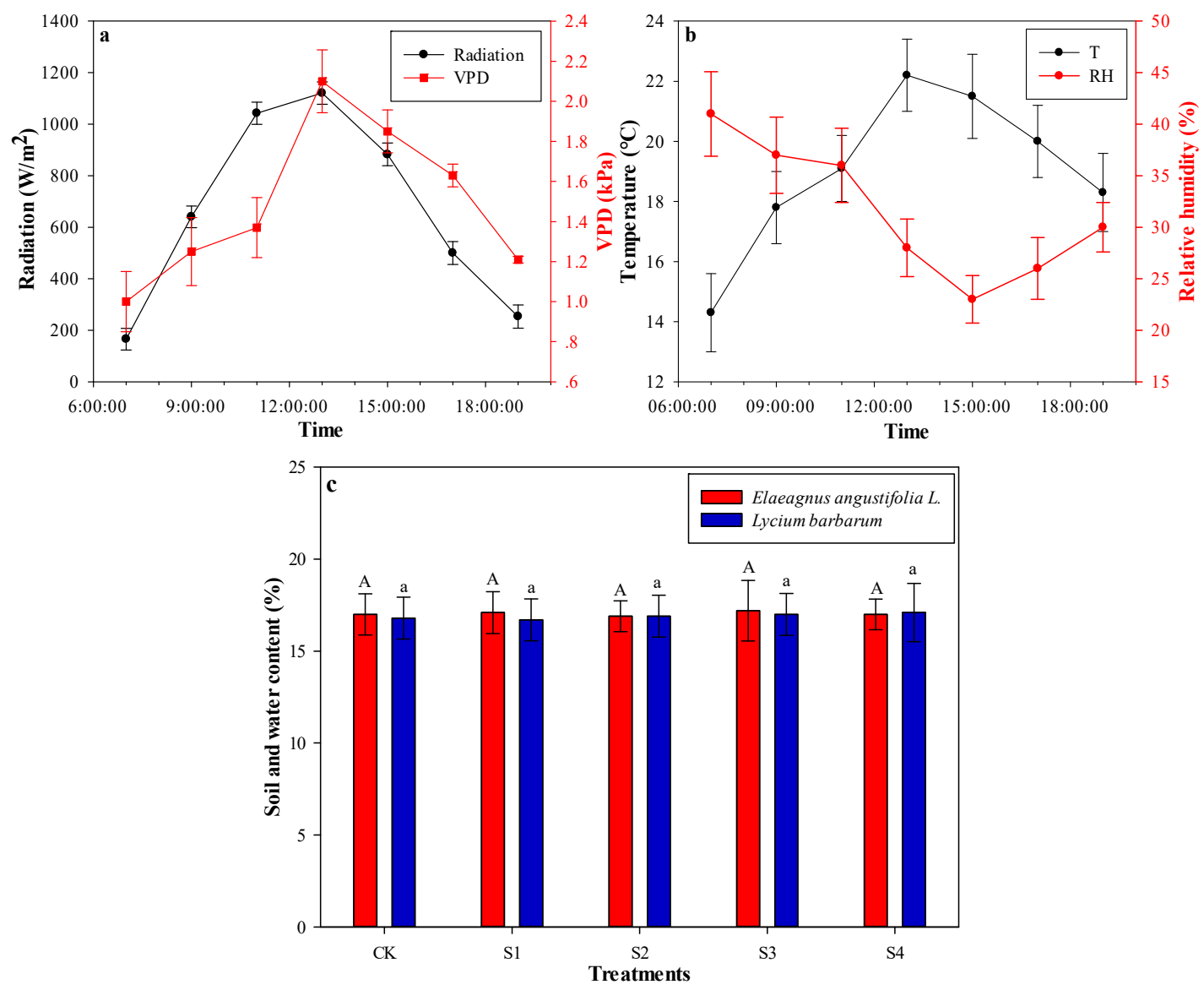

Figure 2. Daily variations in meteorological factors and soil and water content at a typical sunny day. The (a), (b) and (c) were the variation of radiation, temperature and soil and water content, respectively. The data in figure were mean \pm S.D.

\subsection{Effects of Salt Stress on Chlorophyll Content of Shrubs}

The SPAD value can be used as an indicator to reflect the differences in chlorophyll content per unit area of the leaf, which can indicate the relative level of chlorophyll [24] and allows an assumption about the functioning of the entire photosynthetic system [3]. Previous studies have shown that the SPAD value measured by the SPAD chlorophyll meter is highly correlated with the chlorophyll content [25]. The SPAD value indicates that the chlorophyll content can not only perform the non-destructive measurement very conveniently, but also that the scientific data is scientifically rigorous [26]. In general, the SPAD value of E. angustifolia was higher than that of L. barbarum. With increasing salt stress, 
the SPAD values decreased (Figure 3). At a salt concentration of $100 \mathrm{mmol} \cdot \mathrm{L}^{-1}$, the SPAD values were significantly lower than those of the control group $(p<0.05)$, indicating that salt stress can significantly reduce the chlorophyll content in leaves of E. angustifolia and L. barbarum. In E. angustifolia under salt stress, the chlorophyll content decreased significantly with increasing salt concentration $(p<0.05)$. The chlorophyll content of L. barbarum at salt concentrations of 200 and $300 \mathrm{mmol} \cdot \mathrm{L}^{-1}$ was 15.2 and $30.7 \%$ lower, respectively, than that of the control group. However, there was no significant difference in SPAD values of $L$. barbarum at salt concentrations of 300 and $400 \mathrm{mmol} \cdot \mathrm{L}^{-1}$. With increasing salt stress, the SPAD value of E. angustifolia decreased more rapidly than that of L. barbarum, indicating a greater damage to E. angustifolia. Wang et al. have reported that the effects of salt stress on chlorophyll are species-specific, and other studies have shown that salt stress can inhibit the chlorophyll synthesis of plants, which is similar to the inhibition of growth and closely related to salt concentration [26,27]. At higher salt concentrations, plant chlorophyll content generally decreases [28]. Gouveianeto et al. have suggested that the main reason for the decrease in chlorophyll content caused by high salt concentrations is the blocking of the electron transport [29].

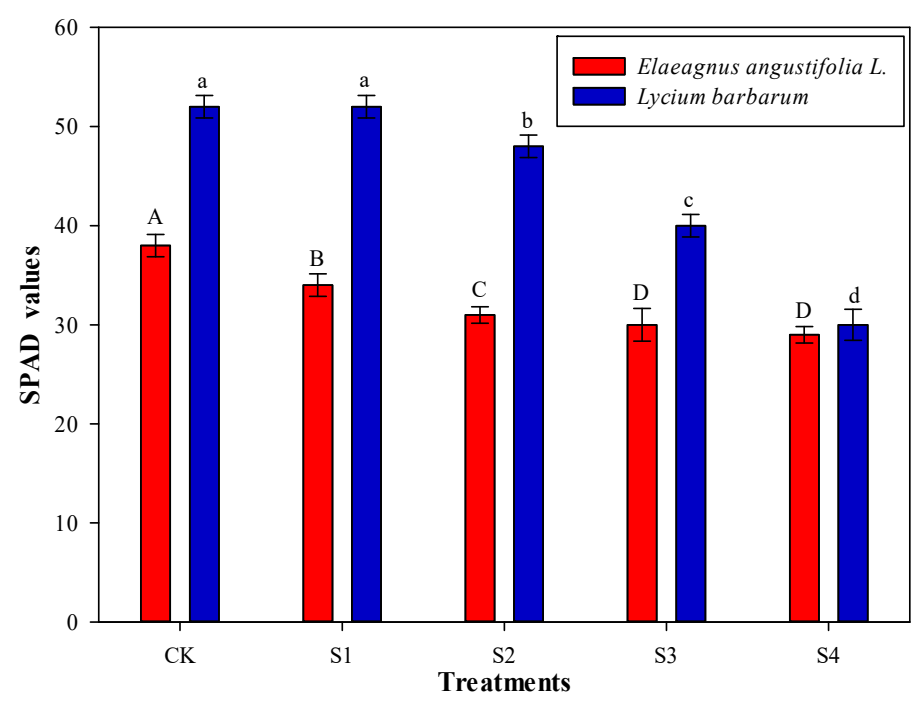

Figure 3. Mean ( \pm S.D.) SPAD values of the shrub species E. angustifolia and L. barbarum at different salt concentrations. The SPAD is Soil and Plant Analyzer Development. The CK, S1, S2, S3, S4 were the salt concentrations were $0,100,200,300$ and $400 \mathrm{mmol} \cdot \mathrm{L}^{-1}$, respectively. Uppercase and lowercase letters indicate significant differences among treatments for E. angustifolia and L. barbarum, respectively, at $p<0.05$ with $\mathrm{T}$ test.

\subsection{Effects of Salt Stress on Photosynthesis}

Numerous studies have shown that salt-alkaline stress can inhibit plant photosynthesis, which is similar to the inhibition of growth and is closely related to the salt concentration [30-32]. The net photosynthetic rates of E. angustifolia and L. barbarum decreased with increasing salt stress $(p<0.05)$ (Figure 4), indicating inhibition of photosynthesis. Doubnerová and Ryšlaváhave suggested that when the salt concentration in the soil exceeds a certain threshold, photosynthesis is inhibited [33]. According to our results, the diurnal variation of photosynthesis rate of E. angustifolia and $L$. barbarum represented a bimodal curve. The photosynthetic lunch break of the control is about 13:00. The photosynthetic lunch break of the salt treatment occurs at around 11:00. The second peak appeared at around 15:00, although the photosynthetic rate of the first peak was significantly larger than that of the second peak. The daily mean value of the net photosynthetic rate also decreased with increasing salt stress, with values for E. angustifolia at 100, 200, 300, and $400 \mathrm{mmol} \cdot \mathrm{L}^{-1}$ of $5.22,4.47,3.31$, and 2.14 $\mu \mathrm{mol} \cdot \mathrm{m}^{-2} \cdot \mathrm{s}^{-1}$, being $8.14,21.43,41.88$, and $62.33 \%$ lower than those of the control group, respectively $(p<0.05)$. 
For L. barbarum, the diurnal variation of the net photosynthetic rate showed a "double peak" curve under salt stress. With increasing temperature, solar radiation, and saturated water vapor pressure difference, the net photosynthetic rate of L. barbarum in each treatment group increased rapidly from 7:00 to 11:00 and reached its peak value for the first time at 11:00, with values of $27.23,26.80,14.78,9.56$, and $8 \mu \mathrm{mol} \cdot \mathrm{m}^{-2} \cdot \mathrm{s}^{-1}$, respectively $(p<0.05)$. The net photosynthetic rate of L. barbarum was significantly lower than that of the control group when the concentration was higher than $100 \mathrm{mmol} \cdot \mathrm{L}^{-1}$. At 11:00-15:00, the solar radiation and temperature reached the highest values, and stomatal regulation was carried out by L. barbarum to prevent excessive water loss. At 15:00, the second photosynthesis peak occurred, with $21.62 \mu \mathrm{mol} \cdot \mathrm{m}^{-2} \cdot \mathrm{s}^{-1}, 19.70 \mu \mathrm{mol} \cdot \mathrm{m}^{-2} \cdot \mathrm{s}^{-1}$, $11.42 \mu \mathrm{mol} \cdot \mathrm{m}^{-2} \cdot \mathrm{s}^{-1}, 9.46 \mu \mathrm{mol} \cdot \mathrm{m}^{-2} \cdot \mathrm{s}^{-1}$ and $7.85 \mu \mathrm{mol} \cdot \mathrm{m}^{-2} \cdot \mathrm{s}^{-1}$ at $0 \mathrm{mmol} \cdot \mathrm{L}^{-1}, 100 \mathrm{mmol} \cdot \mathrm{L}^{-1}$, $200 \mathrm{mmol} \cdot \mathrm{L}^{-1}, 300 \mathrm{mmol} \cdot \mathrm{L}^{-1}$, and $400 \mathrm{mmol} \cdot \mathrm{L}^{-1}$, respectively.

The salt concentration of $100 \mathrm{mmol} \cdot \mathrm{L}^{-1}$ had no significant effect on net photosynthesis of $L$. barbarum. However, at concentration above $100 \mathrm{mmol} \cdot \mathrm{L}^{-1}$, the net photosynthesis rate of L. barbarum showed a significant downward trend and decreased by $41.1 \%, 55.5 \%$, and $66.3 \%$ at $200 \mathrm{mmol} \cdot \mathrm{L}^{-1}$, $300 \mathrm{mmol} \cdot \mathrm{L}^{-1}$, and $400 \mathrm{mmol} \cdot \mathrm{L}^{-1}$, respectively $(p<0.05)$. The maximum net photosynthesis rate of $L$. barbarum decreased more significantly than that of E. angustifolia, indicating a stronger effect of $\mathrm{NaCl}$ on L. barbarum. Several studies have suggested two main reasons for the decrease in net photosynthetic rate under saline-alkaline stress, namely stomatal restriction caused by partial closure of stomata and decreased cell viability [34-36]. The decrease in intercellular carbon dioxide concentration and stomatal conductance were the main reasons for the decreased photosynthesis rates [37].

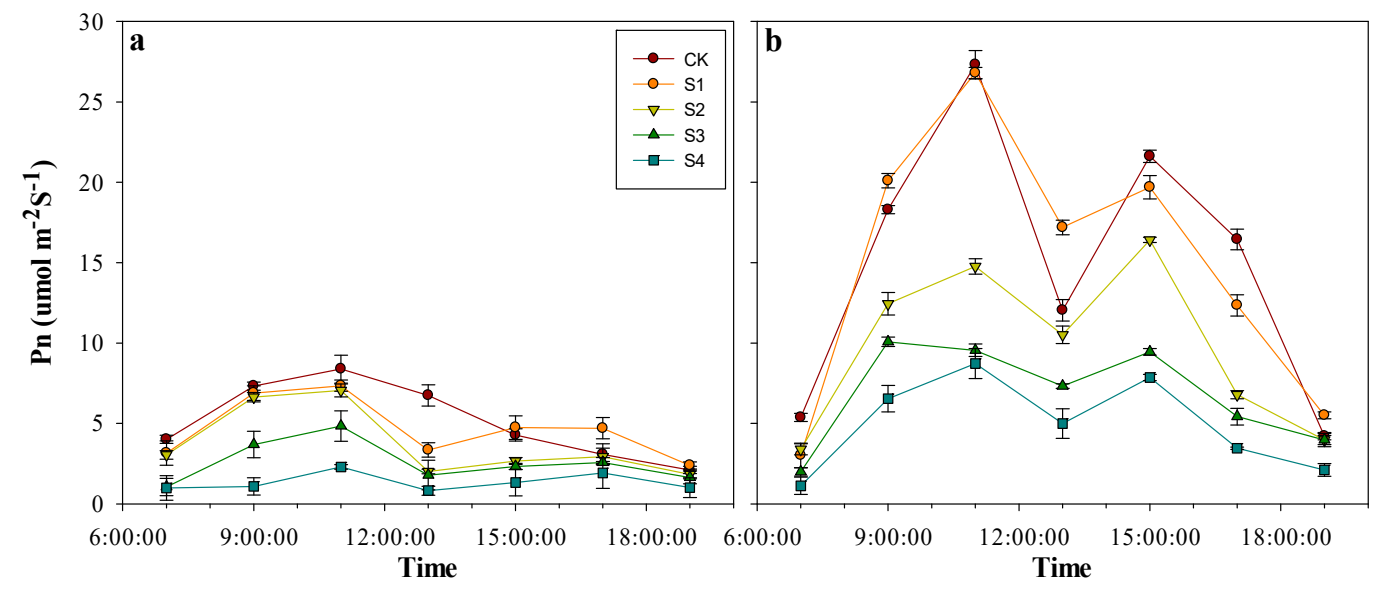

Figure 4. Changes in mean ( \pm S.D.) net photosynthetic rates of the shrub species E. angustifolia and $L$. barbarum at different salt concentrations throughout the day. The (a) and (b) in bold are represented $E$. angustifolia and L. barbarum respectively.

\subsection{Effects of Salt Stress on Transpiration}

Transpiration was the main pathway of water loss and reflects the potential of plant water consumption and adaptability to the environmental changes. With increasing salt stress, the peak value of the transpiration rate of E. angustifolia decreased gradually (Figure 5). The diurnal variation in transpiration rate of E. angustifolia was comparable to that in net photosynthesis rate, which showed a bimodal curve. The two peaks appeared at the same time under different treatments $(p<0.05)$. The first peak was around 11:00 a.m., while the second and lower peak was observed at about 15:00. The daily mean values of the S1 to S4 treatments were $70.74 \%, 60.52 \%, 36.25 \%$, and $22.14 \%$ lower than that of the control group, respectively $(p<0.05)$.

For L. barbarum, the diurnal variation in transpiration rate showed a "double peak" curve under salt stress. With increasing temperature, solar radiation, and saturated water vapor pressure difference, the net transpiration rate of L. barbarum in each treatment group increased rapidly from 7:00 to 11:00 and reached its peak value for the first time at 11:00, with peak values of $15.48 \mathrm{mmol} \cdot \mathrm{m}^{-2} \cdot \mathrm{s}^{-1}$, 
$14.22 \mathrm{mmol} \cdot \mathrm{m}^{-2} \cdot \mathrm{s}^{-1}, 10.86 \mathrm{mmol} \cdot \mathrm{m}^{-2} \cdot \mathrm{s}^{-1}, 5.50 \mathrm{mmol} \cdot \mathrm{m}^{-2} \cdot \mathrm{s}^{-1}$, and $3.81 \mathrm{mmol} \cdot \mathrm{m}^{-2} \cdot \mathrm{s}^{-1}$, respectively. The transpiration rate of L. barbarum was significantly lower than that of the control group when the concentration was higher than $100 \mathrm{mmol} \cdot \mathrm{L}^{-1}$. At 11:00-15:00, solar radiation and temperature reached the highest values, and L. barbrum carried out stomatal regulation to prevent excessive water loss. At 15:00, the second transpiration peaks occurred, with $16.61,15.09,7.07,4.38$, and $3.61 \mathrm{mmol} \cdot \mathrm{m}^{-2} \cdot \mathrm{s}^{-1}$ at $0,100,200,300$, and $400 \mathrm{mmol} \cdot \mathrm{L}^{-1}$, respectively $(p<0.05)$. The transpiration rates of $L$. barbarum were decreased by $39.8,68.3$, and $75.4 \%$ at 200,300 , and $400 \mathrm{mmol} \cdot \mathrm{L}^{-1}$, respectively $(p<0.05)$. The maximum net photosynthetic rate of L. barbarum decreased more significantly than that of E. angustifolia, again indication a more distinct effect of $\mathrm{NaCl}$ on L. barbarum. Andriani et al. have also found that the transpiration rate of shrubs decreased gradually under salt stress [38]. According to Farquhar's classical theory, when both intercellular carbon dioxide concentration and stomatal conductance show a downward trend at the same time, the reason for the inhibition of plant photosynthesis under stress is stomatal limitation, in contrast to non-stomatal limitation [39]. According to a previous study, the decrease in intercellular carbon dioxide concentration and stomatal conductance are the main reasons for the decrease in transpiration rate [40].

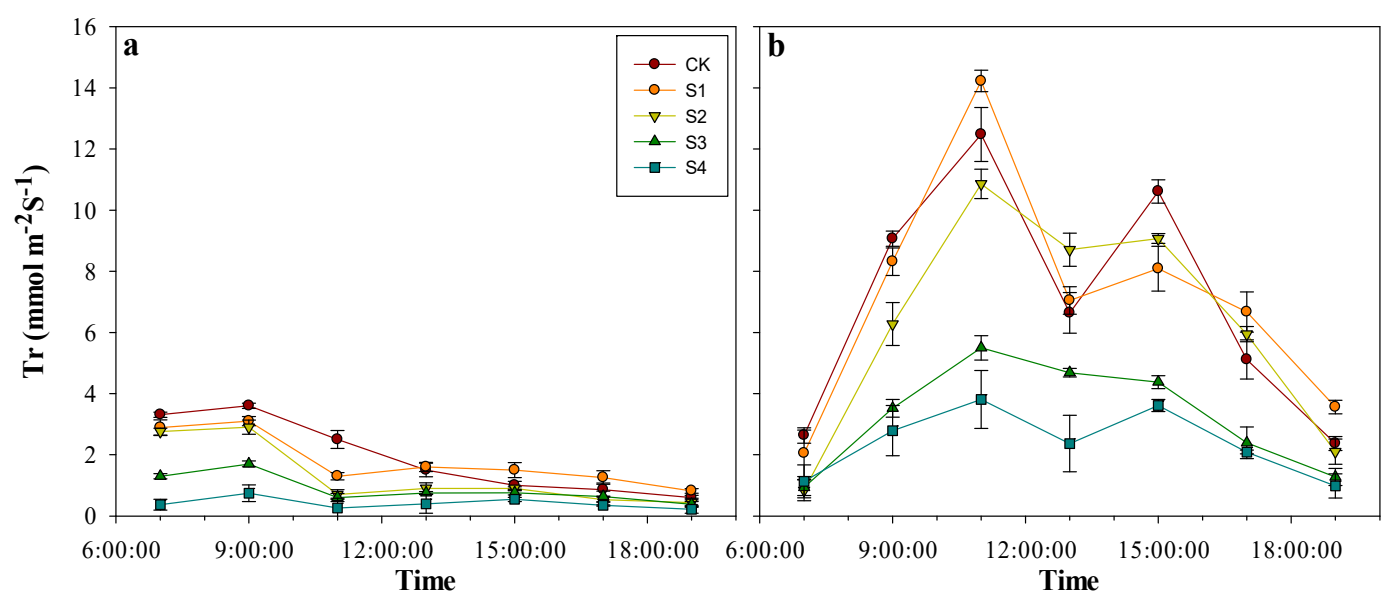

Figure 5. Changes in mean ( \pm S.D.) transpiration rates of the shrub species E. angustifolia and L. barbarum at different salt concentrations throughout the day. The (a) and (b) in bold are represented E. angustifolia and L. barbarum respectively.

\subsection{Effects of Salt Stress on Water Use Efficiency}

The WUE of E. angustifolia under salt stress was significantly higher than that of the control $(p<$ 0.05; Figure 6). The daily mean values of WUE of E. angustifolia under the treatments S1-S4 were 109.41, $119.74,135.28$, and $156.01 \%$, respectively. Although $\mathrm{NaCl}$ salt stress can reduce the photosynthesis and transpiration rates of E. angustifolia, it improves water use efficiency in this species, and the difference between the two species will gradually increase with increasing $\mathrm{NaCl}$ concentrations. Yue et al. and Farissi et al. have found similar variation in Kosteletzfkya virginica L. Presl and Quercus aliena [41,42]. Since E. angustifolia is a salt-tolerant plant species [43], under salt stress, it reduces its water consumption and therefore improves its water use efficiency. However, the WUE of L. barbarum under salt stress was not significantly different from that of the control group $(p>0.05)$. 


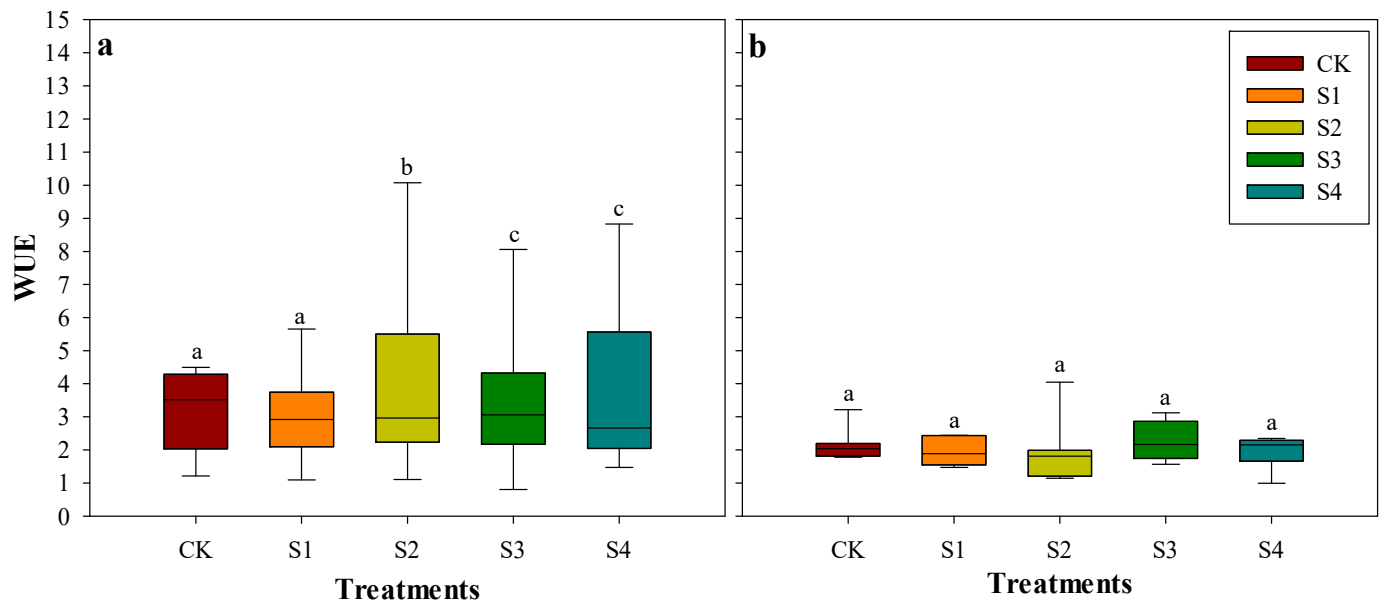

Figure 6. Changes in mean ( \pm S.D.) water use efficiency of the shrub species E. angustifolia and $L$. barbarum at different salt concentrations throughout the day. The (a) and (b) in bold are represented E. angustifolia and L. barbarum respectively. Lowercase letters indicate significant differences among treatments for E. angustifolia and L. barbarum, respectively, at $p<0.05$ with T test.

\subsection{Evaluation of the Effect of Saline Stress on E. angustifolia and L. barbarum}

The use of only one indicator does not adequately reflect salt tolerance [44], making it necessary to comprehensively compare and analyze multiple indicators [45]. Different scholars also use different methods for the evaluation of salt tolerance in different plant species [45]. In this study, 10 photosynthetic indices, including T, SPAD, $P_{n}, G_{s}, C_{i}, T_{r}, P_{n \max }, A Q Y, R D, L C P$, and LSP, were determined under salt-alkaline stress. The correlation between the above indices and salt concentration was analyzed, and the chlorophyll contents with the highest correlation coefficient and net photosynthetic rate were selected to characterize the overall photosynthetic system (Table 2). The results showed that under $\mathrm{NaCl}$ stress, with increasing salt concentrations, the salt tolerance of E. angustifolia and L. barbarum was increased. Chlorophyll content and net photosynthetic rate were fitted with the salt-alkaline concentration, and the salt concentration was taken as the salt-alkaline tolerance threshold when each index exceeded $50 \%$ of that of the control group. The threshold was calculated via a regression equation. The thresholds of the effects of salt stress on chlorophyll content and net photosynthetic rate were 128.4 and $108.4 \mathrm{mmol} \cdot \mathrm{L}^{-1}$, respectively. The minimum value of $108.4 \mathrm{mmol} \cdot \mathrm{L}^{-1}$ was taken as the salt tolerance threshold of E. angustifolia. The thresholds of the effects of salt stress on chlorophyll content and net photosynthetic rate were 263.2 and $246.3 \mathrm{mmol} \cdot \mathrm{L}^{-1}$, respectively, and the minimum value of $246.3 \mathrm{mmol} \cdot \mathrm{L}^{-1}$ was taken as the salt tolerance threshold of L. barbarum. The salt tolerance of L. barbarum was higher than that of E. angustifolia under $\mathrm{NaCl}$ concentrations of $100,200,300$, and $400 \mathrm{mmol} \cdot \mathrm{L}^{-1}$. 
Table 2. Correlation matrix of the photosynthetic indices of the shrub species Elaeagnus angustifolia and Lycium barbarum at different salt concentrations.

\begin{tabular}{|c|c|c|c|c|c|c|c|c|c|c|c|c|}
\hline Species & & $\mathrm{T}$ & SPAD & $\mathbf{P}_{\mathbf{n}}$ & $\mathrm{G}_{\mathrm{s}}$ & $\mathrm{C}_{\mathrm{i}}$ & $T_{r}$ & $P_{\text {nmax }}$ & AQY & RD & LCP & LSP \\
\hline \multirow{11}{*}{ Elaeagnus angustifolia L. } & $\mathrm{T}$ & 1 & - & - & - & - & - & - & - & - & - & - \\
\hline & SPAD & $-0.99 * *$ & 1 & - & - & - & - & - & - & - & - & - \\
\hline & $\mathrm{P}_{\mathrm{n}}$ & $-0.99^{* *}$ & $0.99 * *$ & 1 & - & - & - & - & - & - & - & - \\
\hline & $\mathrm{G}_{\mathrm{s}}$ & $-0.99^{* *}$ & $0.99 * *$ & $0.99 * *$ & 1 & - & - & - & - & - & - & - \\
\hline & $\mathrm{C}_{\mathrm{i}}$ & $-0.99^{* *}$ & $0.99 * *$ & $0.99 * *$ & $0.99 * *$ & 1 & - & - & - & - & - & - \\
\hline & $\mathrm{T}_{\mathrm{r}}$ & -0.11 & 0.7 & 0.04 & -0.006 & -0.012 & 1 & - & - & - & - & - \\
\hline & $P_{\text {nmax }}$ & $0.98^{* *}$ & $-0.99 * *$ & $-0.99 * *$ & $-0.99 * *$ & $-0.99 * *$ & -0.07 & 1 & - & - & - & - \\
\hline & AQY & $0.98^{* *}$ & $-0.95^{* *}$ & $-0.96^{* *}$ & $-0.96^{* *}$ & $-0.95^{* *}$ & -0.15 & $-0.91 * *$ & 1 & - & - & - \\
\hline & $\mathrm{RD}$ & 0.73 * & -0.67 * & -0.68 * & -0.70 * & -0.67 * & -0.13 & $-0.91^{* *}$ & -0.68 * & 1 & - & - \\
\hline & LCP & -0.48 & 0.53 & 0.55 & 0.57 & 0.58 & -0.79 & 0.56 & $0.76^{*}$ & 0.58 & 1 & - \\
\hline & LSP & $0.64 *$ & $-0.65 *$ & $-0.62 *$ & -0.58 & -0.59 & -0.45 & -0.59 & -0.74 * & -0.59 & 0.29 & 1 \\
\hline \multirow{11}{*}{ Lycium barbarum } & $\mathrm{T}$ & 1 & - & - & - & - & - & - & - & - & - & - \\
\hline & SPAD & $-0.95^{* *}$ & 1 & - & - & - & - & - & - & - & - & - \\
\hline & $P_{n}$ & $-0.93^{* *}$ & $-0.93^{* *}$ & 1 & - & - & - & - & & - & - & - \\
\hline & $\mathrm{G}_{\mathrm{s}}$ & -0.84 * & -0.81 * & $-0.94^{* *}$ & 1 & - & - & - & - & - & - & - \\
\hline & $\mathrm{C}_{\mathrm{i}}$ & 0.86 * & 0.81 * & 0.67 & 0.49 & 1 & - & - & - & - & - & - \\
\hline & $\mathrm{T}_{\mathrm{r}}$ & -0.89 * & -0.85 * & $-0.9 *$ & $-0.94^{* *}$ & 0.61 & 1 & - & - & - & - & - \\
\hline & $P_{n \max }$ & $-0.9 * *$ & $-0.9 * *$ & $-0.95^{* *}$ & $-0.95^{* *}$ & 0.61 & $-0.96^{* *}$ & 1 & - & - & - & - \\
\hline & AQY & $-0.88 *$ & $-0.9 * *$ & $-0.95^{* *}$ & $-0.93^{* *}$ & 0.66 & $-0.9 *$ & $-0.9 *$ & 1 & - & - & - \\
\hline & RD & -0.84 * & -0.83 * & $-0.84 *$ & $-0.89 *$ & 0.6 & $-0.97^{* *}$ & $-0.95^{* *}$ & -0.84 * & 1 & - & - \\
\hline & LCP & 0.71 & $0.87 *$ & 0.67 & 0.5 & -0.78 * & 0.59 & 0.66 & 0.7 & 0.64 & 1 & - \\
\hline & LSP & -0.89 * & -0.74 * & -0.79 * & -0.73 & 0.69 & -0.79 & -0.74 & -0.71 & -0.69 * & 0.37 & 1 \\
\hline
\end{tabular}

$\mathrm{T}, \mathrm{SPAD}, \mathrm{P}_{\mathrm{n}}, \mathrm{G}_{\mathrm{s}}, \mathrm{C}_{\mathrm{i}}, \mathrm{T}_{\mathrm{r}}, \mathrm{P}_{\mathrm{nmax}}, \mathrm{AQY}, \mathrm{RD}, \mathrm{LCP}$ and LSP are the temperature, soil and plant analyzer development, net photosynthetic rate, stomatal conductance, intercellular carbon dioxide, transpiration rate, maximum net photosynthetic rate, initial quantum efficiency, dark breathing rate, light compensation point and light saturation point, respectively. ${ }^{* *} p<0.01$; $* p<0.05$. 


\section{Conclusions}

The pioneering tree species of jujube and alfalfa in the afforestation of saline-alkali land in northwestern China have already exerted important ecological, economic and social benefits. The salinization of the Qaidam Basin has become increasingly serious and significantly limits the economic development of the region. The photosynthetic parameters of the shrub species E. angustifolia were more sensitive to salinity than those of L. barbarum. The decrease in photosynthetic parameters of both shrub species was due to the combination of stomatal and non-stomatal constraints. The results of correlation matrix of photosynthetic index also indicated that the minimum salt tolerance of $E$. angustifolia and L. barbarum were $108.4 \mathrm{mmol} \cdot \mathrm{L}^{-1}$ and $246.3 \mathrm{mmol} \cdot \mathrm{L}^{-1}$, respectively. According to the salt tolerance thresholds of different plant species, suitable species can be selected for revegetation programs to facilitate the improvement of saline-alkaline soils. For example, ideal planting and development conditions for E. angustifolia could be in the $0-108.4 \mathrm{mmol} \cdot \mathrm{L}^{-1}$ of soil salt concentration; but it was more suitable to plant L. barbarum in $108.4-246.3 \mathrm{mmol} \cdot \mathrm{L}^{-1}$ of soil salt concentration. In field production, when the salt and alkali concentration of soil solution exceeds this threshold, irrigation should be carried out in time.

Author Contributions: T.Z. wrote the paper; Z.Z. conceived and designed the experiments; Y.L. analyzed the data; K.H. performed the experiments and collected the data.

Funding: The study was supported by Province key scientific and technological Projects, Qinghai province, China (Grant No. 2014-NK-A4-4).

Acknowledgments: We thank LetPub (www.letpub.com) for its linguistic assistance during the preparation of this manuscript.

Conflicts of Interest: The authors declare no conflict of interest.

\section{References}

1. Jesus, J.; Castro, F.; Niemelä, A.; Borges, M.T.; Danko, A.S. Evaluation of the impact of different soil salinization processes on organic and mineral soils. Water Air Soil Pollut. 2015, 226, 1-12. [CrossRef]

2. Satoshi, Y. Responses of crops to soil salinization in south Baja California, Mexico. J. Plant Nutr. 2008, 31, 1800-1810. [CrossRef]

3. Zhou, H.; Li, W. The effects of oasis ecosystem hydrological processes on soil salinization in the lower reaches of the tarim river, China. Ecohydrology 2013, 6, 1009-1020. [CrossRef]

4. Haj-Amor, Z.; Hashemi, H.; Bouri, S. Soil salinization and critical shallow groundwater depth under saline irrigation condition in a Saharan irrigated land. Arabian J. Geosci. 2017, 10, 301. [CrossRef]

5. Schofield, R.V.; Kirkby, M.J. Application of salinization indicators and initial development of potential global soil salinization scenario under climatic change. Glob. Biogeochem. Cycles. 2003, 17. [CrossRef]

6. Qin, Y.; Druzhinina, I.S.; Pan, X.; Yuan, Z. Microbially mediated plant salt tolerance and microbiome-based solutions for saline agriculture. Biotechnol. Adv. 2016, 34, 1245-1259. [CrossRef]

7. Wang, M.; Xie, B.; Fu, Y.; Dong, C.; Hui, L.; Guang, H.L.; Liu, H. Effects of different elevated $\mathrm{CO}_{2}$ concentrations on chlorophyll contents, gas exchange, water use efficiency, and psii activity on C3 and C4 cereal crops in a closed artificial ecosystem. Photosynth. Res. 2015, 126, 351-362. [CrossRef]

8. Berguerand, N.; Marinkovic, J.; Vilches, T.B.; Thunman, H. Use of alkali-feldspar as bed material for upgrading a biomass-derived producer gas from a gasifier. Chem. Eng. J. 2016, 295, 80-91. [CrossRef]

9. Tao, Y.; Wu, G.L.; Zhang, Y.M. Dune-scale distribution pattern of herbaceous plants and their relationship with environmental factors in a saline-alkali desert in central Asia. Sci. Total Environ. 2017, 576, 473-480. [CrossRef]

10. Martín-Alfonso, J.E.; López-Beltrán, F.; Valencia, C.; Franco, J.M. Effect of an alkali treatment on the development of cellulose pulp-based gel-like dispersions in vegetable oil for use as lubricants. Tribol. Int. 2018, 123. [CrossRef]

11. Peng, M.; Jia, H.; Wang, Q. The effect of land use on bacterial communities in saline-alkali soil. Curr. Microbiol. 2017, 74, 325-333. [CrossRef] [PubMed] 
12. Ramos-Alemán, F.; González-Jasso, E.; Pless, R.C. Use of alternative alkali chlorides in RT and PCR of polynucleotides containing G quadruplex structures. Analytical Biochem. 2018, 543, 43. [CrossRef] [PubMed]

13. Czinkota, I.; Issa, I.; Rétháti, G.; Kovács, B. Determination of the behaviour and the transport parameters of chromium in soil-water systems. Agrokémia És Talajtan. 2007, 55, 287-294. [CrossRef]

14. Patel, A.D.; Panchal, N.S.; Pandey, I.B.; Pandey, A.N. Growth, water status and nutrient accumulation of seedlings of jatropha curcas 1. (euphorbiaceae) in response to soil salinity. Anales De Biología 2010, 52, 59-71. [CrossRef]

15. Zhou, H.; Li, W. Effect of water resource on soil salinization of oasis in the lower reaches of tarim river, China. Proced. Environ. Sci. 2011, 11, 925-933. [CrossRef]

16. Laplante, S.R.; Fader, L.D.; Fandrick, K.R.; Fandrick, D.R.; Hucke, O.; Kemper, R.; Miller, S.P.F.; Edwards, P.J. Assessing atropisomer axial chirality in drug discovery and development. J. Med. Chem. 2011, $54,7005$. [CrossRef] [PubMed]

17. Guo, W.; Cong, Y.; Hussain, N.; Wang, Y.; Liu, Z.; Jiang, L.; Liang, Z.; Chen, K. The remodeling of seedling development in response to long-term magnesium toxicity and regulation by aba-della signaling in arabidopsis. Plant Cell Physiol. 2014, 55, 1713-1726. [CrossRef]

18. Patel, N.T.; Pandey, A.N. Effect of soil salinity on growth, water status and nutrient accumulation in seedlings of suaeda nudiflora (chenopodiaceae). Anales De Biología 2009, 31, 61-70. [CrossRef]

19. Fraga, T.I.; Carmona, F.D.C.; Anghinoni, I.; Marcolin, E. Attributes of irrigated rice and soil solution as affected by salinity levels of the water layer atributos de arroz irrigado e da solução do solo influenciados por níveis de salinidade da lâmina de água de irrigação. Revista Brasileira De Ciência Do Solo 2010, 34, 1049-1057. [CrossRef]

20. Darlington, A.M.; Jarisz, T.A.; Dewaltkerian, E.L.; Roy, S.; Sun, K.; Azam, M.S. Separating the ph-dependent behavior of water in the stern and diffuse layers with varying salt concentration. J. Phys. Chem. C. 2017, 121. [CrossRef]

21. Aryal, D.; Ganesan, V. Reversal of salt concentration dependencies of salt and water diffusivities in polymer electrolyte membranes. Acs Macro Lett. 2018, 7, 739-744. [CrossRef]

22. Caruso, C.; Maucieri, C.; Berruti, A.; Borin, M.; Barbera, A.C. Responses of Different Panicum miliaceum L. Genotypes to Saline and Water Stress in a Marginal Mediterranean Environment. Agronomy 2018, 8, 8. [CrossRef]

23. Maucieri, C.; Caruso, C.; Bona, S.; Borin, M.; Barbera, A.C.; Cavallaro, V. Influence of salinity and osmotic stress on germination process in an old sicilian landrace and a modern cultivar of Triticum Durum Desf. Cereal Res. Commun. 2018, 46, 253-262. [CrossRef]

24. Ibrahim, M.H.; Jaafar, H.Z.E. Relationship between extractable chlorophyll content and spad values in three varieties of kacip fatimah under greenhouse conditions. J. Plant Nutr. 2013, 36, 1366-1372. [CrossRef]

25. Anand, M.H.; Byju, G. Chlorophyll meter and leaf colour chart to estimate chlorophyllcontent, leaf colour, and yield of cassava. Photosynthetica 2008, 46, 511-516. [CrossRef]

26. Wang, X.; Geng, S.; Ma, Y.; Shi, D.; Yang, C.; Wang, H. Growth, photosynthesis, solute accumulation, and ion balance of tomato plant under sodium- or potassium-salt stress and alkali stress. Agron. J. 2015, 65, 927-928. [CrossRef]

27. Bergmann, I.; Geiß-Brunschweiger, U.; Hagemann, M.; Schoor, A. Salinity tolerance of the chlorophyll b -synthesizing cyanobacterium prochlorothrix hollandica, strain sag 10.89. Microb. Ecol. 2008, 55, 685-696. [CrossRef] [PubMed]

28. Yildirim, E.; Turan, M.; Guvenc, I. Effect of foliar salicylic acid applications on growth, chlorophyll, and mineral content of cucumber grown under salt stress. J. Plant Nutr. 2008, 31, 593-612. [CrossRef]

29. Gouveianeto, A.S.; Silva, E.A.J.; Oliveira, R.A.; Moura, D.S.; Cunha, P.C.; Costa, E.B.; Câmara, T.J.R.; Willadino, L.G. Water deficit and salt stress diagnosis through led induced chlorophyll fluorescence analysis in jatropha curcas 1. oil plants for biodiesel. J. Fluoresc. 2011, 22, 623-630. [CrossRef]

30. Yang, C.W.; Wang, P.; Li, C.Y.; Shi, D.C.; Wang, D.L. Comparison of effects of salt and alkali stresses on the growth and photosynthesis of wheat. Photosynthetica 2008, 46, 107-114. [CrossRef]

31. Wang, Y.; Yan, L. Land exploitation resulting in soil salinization in a desert-oasis ecotone. Catena. 2013, 100, 50-56. [CrossRef]

32. Silva, E.N.D.; Ribeiro, R.V.; Ferreirasilva, S.L.; Viégas, R.A.; Silveira, J.A.G. Salt stress induced damages on the photosynthesis of physic nut young plants. Scientia Agricola. 2011, 68, 62-68. [CrossRef] 
33. Doubnerová, V.; Ryšlavá, $\mathrm{H}$. What can enzymes of $\mathrm{C}_{4}$, photosynthesis do for $\mathrm{C}_{3}$, plants under stress? Plant Sci. 2011, 180, 575-583. [CrossRef] [PubMed]

34. Andriani, A.; Tachibana, S.; Itoh, K. Effects of saline-alkaline stress on benzo[a]pyrene biotransformation and ligninolytic enzyme expression by Bjerkandera adusta, SM46. World J. Microbiol. Biotechnol. 2016, 32, 1-16. [CrossRef] [PubMed]

35. Mercedes-Martín, R.; Rogerson, M.R.; Brasier, A.T.; Vonhof, H.B.; Prior, T.J.; Fellows, S.M.; Reijmer, J.J.G.; Billing, I.; Pedleya, H.M. Growing spherulitic calcite grains in saline, hyperalkaline lakes: Experimental evaluation of the effects of Mg-clays and organic acids. Sediment. Geol. 2016, 335, 93-102. [CrossRef]

36. Krishnamurthy, S.L.; Sharma, P.C.; Sharma, D.K.; Ravikiran, K.T.; Singh, Y.P.; Mishra, V.K.; Burman, D.; Maji, B.; Mandal, S.; Sarangi, S.K.; et al. Identification of mega-environments and rice genotypes for general and specific adaptation to saline and alkaline stresses in India. Sci. Rep. 2017, 7, 7968. [CrossRef] [PubMed]

37. Sorokin, D.Y.; Kolganova, T.V.; Khijniak, T.V.; Jones, B.E.; Kublanov, I.V. Diversity of cultivated aerobic poly-hydrolytic bacteria in saline alkaline soils. Peerj 2017, 2017, 3796. [CrossRef]

38. Noormets, A.; Sôber, A.; Pell, E.J.; Dickson, R.E.; Podil, G.K.; Sôber, J.; Isebrands, J.G.; Karnosky, D.F. Stomatal and non-stomatal limitation to photosynthesis in two trembling aspen (populus tremuloides michx.) clones exposed to elevated $\mathrm{CO}_{2}$ and/or $\mathrm{O}_{3}$. Plant Cell Environ. 2010, 24, 327-336. [CrossRef]

39. Varonea, L.; Ribas-Carbob, M.; Cardonac, C.; Galléb, A.; Medranob, H.; Gratania, L.; Flexasb, J. Stomatal and non-stomatal limitations to photosynthesis in seedlings and saplings of mediterranean species pre-conditioned and aged in nurseries: Different response to water stress. Environ. Exp. Botany. 2012, 75, 235-247. [CrossRef]

40. Yue, L.J.; Li, S.X.; Ma, Q.; Zhou, X.R.; Wu, G.Q.; Bao, A.K.; Zhang, J.L.; Wang, S.M. NaCl stimulates growth and alleviates water stress in the xerophyte zygophyllum xanthoxylum. J. Arid Environ. 2012, 87, 153-160. [CrossRef]

41. Farissi, M.; Faghire, M.; Bargaz, A.; Bouizgaren, A.; Makoudi, B.; Ghoulam, C. Growth, nutrients concentrations, and enzymes involved in plants nutrition of alfalfa populations under saline conditions. J. Agric. Sci. Technol. 2014, 16, 301-314. [CrossRef]

42. Jiao, Y.; Bai, Z.; Xu, J.; Zhao, M.; Khan, Y.; Hu, Y.; Shi, L. Metabolomics and its physiological regulation process reveal the salt-tolerant mechanism in Glycine soja seedling roots. Plant Physiol. Biochem. 2018, 126, 187-196. [CrossRef] [PubMed]

43. Lee, K.B.; Kang, J.G.; Li, J.; Lee, D.B.; Park, C.W.; Kim, J.D. Evaluation of salt-tolerance plant for improving saline soil of reclaimed land. Korean J. Soil Sci. Fertil. 2007, 40, 173-180.

44. Zhang, X.; Lu, G.; Long, W.; Zou, X.; Li, F.; Nishio, T. Recent progress in drought and salt tolerance studies in brassica crops. Breed Sci. 2014, 64, 60-73. [CrossRef] [PubMed]

45. Talei, D.; Yusop, M.K.; Kadir, M.A.; Abdullah, M.P.; Valdiani, A. Response of king of bitters (andrographis paniculata nees.) seedlings to salinity stress beyond the salt tolerance threshold. Aust. J. Crop Sci. 2012, 6, 1059-1067.

(C) 2019 by the authors. Licensee MDPI, Basel, Switzerland. This article is an open access article distributed under the terms and conditions of the Creative Commons Attribution (CC BY) license (http://creativecommons.org/licenses/by/4.0/). 